superfluous material and constitutes a sound and mathematical concept, chiefly owing to the work of R. A. Fisher, yet, whatever the importance of the process within organic evolution itself, it was not a primary cause.

Clearly cosmic or inorganic evolution must have been at work long before organic evolution ever started, and the primary cause of organic evolution is to be sought. for within the cause of inorganic evolution. It is true that the origin of the universe or even of the solar system is still a much debated question, but no scientific theory yet put forward disregards the law of gravitation, and most include either the concept of maximum entropy or of thermodynamic potential. Clearly none of these concepts is applicable to organisms or tissues of unknown weight or density. One very elementary theoretical outcome of this view may be cited briefly. Without disregarding the fact that there may be no real distinction between the living and non-living in the initial stages, we are justified in assuming that the first free-swimming organisms consisted of protoplasm and existed near the surface of water. Since, however, the density of protoplasm must always exceed that of the water constituting its external environment, the first struggle for existence must have been influenced by gravity and not primarily by competition between individuals. It would appear, therefore, that the accurate determination of weight and density is of fundamental importance for an accurate study of aquatic organisms.

1 Nature, 141, 289 (1938).

'Iowndes, Proc. Linn. Soc., London, 150, Pt. 2 (1937-38).

- Lowndes, J. Mar.-Biol. Assoc., 25, No. 3, 555 (1942).

' Lowndes, Proc. Zool. Soc. London, A, 113, 28 (1943).

${ }^{3}$ Nature, 150, 695 (1942).

'Thompson, Sir D'Arcy, "Growth and Form", 67 (Cambridge, 1942)

\section{THE HORSE-CHESTNUT TREE (AESCULUS HIPPOCASTANUM)}

\section{BY ALEXANDER L. HOWARD}

\author{
"Oh! there the chestnuts, summer through, \\ Beside the river make for you \\ A tunnel of green gloom, and sleep \\ Deeply above."

\section{RUPERT Brooke.}

$\mathrm{T}$ HE horse-chestnut tree is not indigenous to Great Britain but was introduced in the middle of the sixteenth century ; there is some doubt as to its origin, but the general opinion is that it was a native of the Balkan mountains, or perhaps that it was introduced there from Iran, northern India or Tibet. Gerrard speaks of the first tree being heard of in 1579, and from this date it became generally planted throughout western Europe, especially in Sardinia, Sicily and Corsica. In the most favourable circumstances it may attain a height of about $120 \mathrm{ft}$., with a girth of $18 \mathrm{ft}$. , and in Ireland Elwes mentions a tree at Woodstock, Kilkenny, which was $93 \mathrm{ft}$. in height and $18 \mathrm{ft} .1 \mathrm{in}$. in girth. The tree is well known to men, women and children, the former principally for the beauty of its flowers in the early summer, and the latter who wait impatiently for the autumn when they can throw sticks at the branches to dislodge the fruits which contain the seeds or "conkers".
The horse-chestnut (Aesculus hippocastanum) is often mistakenly confused with the sweet-chestnut (Castanea sativa) to which it is not related either in fashion or family. C. A. Johns says that the origin of the name is in doubt. "The name Aesculus, from esca, food, was applied originally to a species of Oak, which, according to Pliny, was highly prized for its acorns, but how it came to be transferred to the Horse Chestnut is very uncertain; perhaps, as Loudon suggests, it was given ironically because its nuts, which are unfit $f$ : $r$ food, bear a great resemblance externally to those of the Spanish Chestnut. Hippocastanum is a translation of its modern name, which was given 'from its curing horses broken-winded and other cattle of coughs" "(Evelyn).

Pliny, according to the translation by Dr. Philemon Holland, does not mention horse-chestnut, but he describes what he calls Esculus, terming it oak. This does not apply to the oak but fits the horse-chestnut. In his time the mountains of Greece abounded with these trees, and it is thought that this was its native habitat. It was introduced and freely planted in Sardinia, Sicily, and Corsica, and Pliny refers to what he calls "the Sardinian nut". Whether by this name he was speaking of the sweet-chestnut or the horse-chestnut is not clear; but it is probable that he was referring to the sweet-chestnut. It seems evident that in his time the tree was valued for its fruit but not for its timber. He says :

"The best mast (nut) and the biggest is the acorne growing upon the common Oke, next to it is that of the Esculus; as for that of the Robur it is but small. The cerrus carrieth a mast unpleasant to the eie, and rough to be handled, for clad it is with a cup beset with sharpe prick like to the Chestnut tree. ...

We entitule Chestens also by the name of Nuts, although indeed they are more aptly to be called a kind of Mast. This fruit whatever it be, is enclosed within a huske, and the same defended and armed all over with a rampier and palaisade (as it were) of sharpe pricks like the skin of an Urchin; whereas the Acorne and other Mast is but half covered, and that defence in them is begun only. And certes, a wonderful matter it is, that we set little store by this fruit, which Nature is so careful to hide and defend. Under one of these husks ye shall find sometime three Chestnuts, and those having certain tough pills or shells very pliable. But the skin or filme within, and which is next to the bodie or substance of the fruit, unless it bee pilled off and taken away, marroth the tast of it, like as it doth also in other nut kernels. Chestnuts, if they be rosted, are better and more pleasant meat than otherwise. They use also to grind them to meale, and thereof is made a kind of bread that poore women for hunger will eat. The first Chestnuts were knowne to grow about Sardis and from thence were brought and therefore the Greeks call them Sardinian nuts."

It is impossible to decide for certain whether he was speaking of the sweet-chestnut or the horsechestnut, but it seems probable that although his description would apply equally to the nuts of either tree, he must have been referring to the former.

At the time of John Evelyn it became fashionable to plant the horse-chestnut in avenues, and many famous examples dating from this time can still be seen in different parts of the British Isles-as well as on the Continent, in private and public parks and gardens. In this way the chestnut shows its full beauty and dignity at all seasons of the year, but specially when its candle-like flowers are in full bloom. One of the most famous chestnut avenues in England is at Bushey Park, Hampton Court, which is visited year by year by many people on Chestnut Sunday.

However it is situated, the horse-chestnut is the 
first of our trees to clothe itself with green leaves, which are different in shape from those of our other forest trees, having five to seven leaflets, 4-9 in. long, and brilliant light green in early spring, deepening to a heavy darker shade and turning to golden yellow before they fall in early autumn.

The bark is smooth of a greenish-brown colour, and the crown generally becomes pyramidal in shape. Sometimes the branches droop, and in cases dig into the ground all round the base of the tree, whence they take root and spring up again, often attaining a much increased girth in the upward growth than that proceeding from the tree in the downward bend. A remarkable tree of this habit is in vigorous health at Hawkhurst Moor, with a height of about $90 \mathrm{ft}$., and covering the ground to a circumference of $285 \mathrm{ft}$.

The yellow horse-chestnut (Aesculus octandra) was first introduced into England in 1764. The red horsechestnut (Ae. carnea) was, according to Elwes, first introduced from Germany in 1818. Both may be seen in almost every garden and park, especially around London and other cities. Neither of these trees attains the dimensions of the common horsechestnut (Ae. hippocastanum).

Ae. pavia, a shrub bearing a red flower, is referred to by Elwes, who says "it closely resembles Aesculus octandra" and supposed to have produced with Ae. hippocastanum the hybrid Ae. carnea. Loudon describes this as "The Pavia, or smooth-fruited Horsechestnut tree" and also mentions $P$. rubra, but the whole subject is so confused that it is difficult, if not impossible, to state accurately the botanical variations.

Both the horse-chestnut and the sweet-chestnut, for some unexplained reason, are subject to spiral growth in the British Isles. During the War of 1914-18, the subject of spiral growth came very much to the fore, as apparently sitka spruce (Picea sitchensis) imported from British Columbia was found to carry this defect more than any other tree for which there was an equal demand. Inquiry into the subject brought suggestions, one of which was that it was a hereditary feature. Although this may be possible, I am more inclined to think that spiral growth is caused by the situation of the tree and its relation to the sun and wind. In Hyde Park, in the triangular piece of ground between the Magazine and the Epstein statue, by the Serpentine, there are twenty-four horse-chestnut trees, all but two of which show spiral growth, a number proportionately much greater than in any other part of the Park. 'This site must be subject to varying winds from different quarters, while the rays of the sun may influence the direction of the growth. At the same time, it is strange that one particular tree should be subject to more spiral growth than anothera subject well worth inquiry.

About 1920, shipments arrived in London, and probably Paris, Hamburg, and Rotterdam, of Japanese horse-chestnut (Aesculus turbinata-the Japanese name for which is 'Tochi-noki'). These shipments consisted of large-sized slabs, or flitches and planks. The wood was similar in colour and texture to that grown in England, but mainly consisted of highly figured wood, rich in roe and splashmottle, some bright and clean, while other was streaked with black marks-denoting incipient decay. All this timber was equally sound and good, while that streaked with black was particularly decorative, and was greatly in demand for art furniture in which it realized high values.
Speaking of the British variety, Elwes mistakenly says :

"The wood of the Horse Chestnut is one of the poorest and least valuable we have, on account of its softness and want of strength and durability. Though it has a fine close and even grain, white or yellowish-white colour, and is not liable to twist or warp so much as most woods, it does not cut cleanly."

Elwes cannot have known the many purposes for which chestnut has been used.

Quoting from "Timbers of the World" :

"If the tree be cut down early in winter, promptly sawn into boards, etc., and carefully stored, wood of extreme whiteness may be obtained. If, however, the trunks are felled later in winter, or are allowed to lie for any length of time, the wood assumes a yellowish-brown tint. It is of moderate weight, soft fine-grained, but perishable; used for making soap-bowls, brush-backs, in turnery, and occasionally for veneers. Even with the developments which have occurred since the war (1914-1918), supplies of horse chestnut are not sufficiently valued or appreciated. In Southern Europe it is said to have been used for fruit. storing shelves; the porous nature of the wood absorbs the moisture from the fruit, the preservation of which is thereby assisted."

Besides its use for gunpowder and charcoal, the timber is most valuable for furniture and works of decorative art, for which purpose it has been by far too little appreciated.

\section{STATISTICS IN GOVERNMENT DEPARTMENTS}

A MEMORANDUM on the Post-War Organization of Statistics in Government Departments, which has been prepared by the Institution of Professional Civil Servants for submission to the Treasury, draws largely on material in the Memorandum on Official Statistics issued by the Royal Statistical Society, with the recommendations of which the Institution to a considerable extent agrees, apart from certain proposals with regard to the structure of the statistical service and the status of its officers. The Institution's own proposals are set out under five headings. First, with regard to the functions of a statistical service, it is considered that the work of the statistical service should be an integral part of the administration, including such public functions as the collection, presentation and publication of a continuous series of statistics relating to the economic and social condition of the nation; the interpretation and enlargement for publication of material already covered in part by existing statistics, together with explora. tions into fields not hitherto covered, so as to provide industry and trade with information which by its nature can only be collected through the agency of the Government; and research inta the statistical aspects of social questions. One internal function should be provision of the pre-requisites of policy formation, and the memorandum claims that the statistician, in providing material on the quantitative aspects of a probfem, should be called upon to play his part in deciding how things planned for the future are to be attained.

Next, with regard to grades, salary, promotion and superannuation of statistical staff, the Institution urges that there should be only two classes of statistician; a principal statistician class, with career value comparable with that of the administra. tive class of the Civil Service, and an executive 